\title{
A JURISPRUDÊNCIA DO SUPREMO TRIBUNAL FEDERAL SOBRE O CONTROLE JUDICIAL DO ORÇAMENTO PÚBLICO E A PROTEÇÃO DOS DIREITOS HUMANOS
}

\author{
Ana Paula Oliveira Ávila ${ }^{1}$ \\ Daniella Bitencourt ${ }^{2}$
}

\section{RESUMO}

Este artigo apresenta um panorama da jurisprudência do Supremo Tribunal Federal sobre o controle judicial do orçamento público e a proteção dos direitos humanos enquanto fim do Estado e do direito, especialmente considerando a recente tese fixada sobre o assunto. A questão de saber se é possível conciliar a atividade judicial com o controle de constitucionalidade dos orçamentos públicos é complexa e polêmica. Diante disso, para além de analisar as implicações orçamentárias decorrentes da judicialização dos direitos sociais positivos, o objetivo do presente estudo é analisar a postura do Poder Judiciário (STF) com relação ao próprio orçamento.

Palavras-chave: Direitos Humanos, Orçamento Público, Controle Jurisdicional, Supremo Tribunal Federal.

\section{BRAZILIAN SUPREME COURT'S RULINGS REGARDING JUDICIAL REVIEW OF THE PUBLIC BUDGET AND THE PROTECTION OF HUMAN RIGHTS}

\begin{abstract}
This article presents the evolution on the Brazilian Supreme Court jurisprudence involving public budget review, in the light of the human and fundamental rights promotion as a state's goal specially regarding the most recent court's ruling on this issue. The question regarding the possibility to reconcile judicial review with public budget control is a complex one. In analyzing its complexity, this study aims at the effects that litigation over economic and social rights produces on public budget and what kind of attitude should we expect from the Judiciary regarding public budget planning.
\end{abstract}

Key-words: Human Rights. Public Budget. Judicial Review. Constitutional Court.

\section{Introdução}

\footnotetext{
${ }^{1}$ Mestre e Doutora pela Universidade Federal do Rio Grande do Sul - UFRGS. Professora Titular de Direito Constitucional do UniRitter - Graduação e Mestrado.

${ }^{2}$ Mestranda em Direitos Humanos, linha de pesquisa Direitos Humanos, Estado de Direito e Constitucionalismo pela Uniritter (Atual). Especialista em Impostos em Espécie pela UFRGS (2012) e Direito Tributário pela Universidade Mackenzie/SP (2005). Graduada pela Ritter dos Reis (2003) Professora de Direito Tributário na Anhanguera Educacional (2016).
} 
Este artigo apresenta um panorama da jurisprudência do Supremo Tribunal Federal - STF relacionada ao orçamento público, especialmente considerando a recente tese fixada sobre o assunto no julgamento da ADI n. 5468, em junho de 2016. A importância do tema está no fato de que o orçamento é elemento central dos direitos fundamentais individuais, sociais e econômicos, uma vez que é nele que estão articulados os recursos necessários à promoção do Estado Social de Direito. Noutras palavras, a satisfação de um grande número de direitos constitucionais do cidadão passa pelo desenho orçamentário. Nesse contexto, saber se o Poder Judiciário poderá intervir no Poder Público, como fiscalizador dos recursos públicos destinados aos direitos fundamentais, é de vital importância para promover a efetivação da dignidade da pessoa, enquanto fim do Estado e também do direito.

A questão de saber se é possível conciliar a atividade judicial com o controle de constitucionalidade do orçamento público é verdadeiramente complexa e polêmica, pois envolve a definição dos limites da atuação do Poder Judiciário enquanto guardião da Constituição Federal, além de ser um debate multidisciplinar que toca em diversos princípios fundamentais do Estado Democrático de Direito.

Deste modo, as relações envolvendo a implementação de direitos sociais oponíveis ao Estado perante o Poder Judiciário implicam o questionamento sobre a legitimidade deste poder para definir a destinação dos recursos públicos, tarefa que normalmente incumbe aos poderes políticos - assim considerados aqueles que congregam os representantes eleitos pela sociedade, tais como o Poder Executivo e o Legislativo. David Beatty (2014, p.284), em seu livro "A essência do Estado de Direito", apresenta um estudo da jurisprudência de vários países e analisa a função dos tribunais em relação ao tema, informando que muitos juízes são categóricos ao afirmar que não se deve confiar aos tribunais decisões políticas, sociais e econômicas, devido ao fato de que essa postura judicial seria inaceitável por ensejar um total rompimento com o Princípio da Separação dos Poderes e uma grave limitação à soberania do povo.

Mesmo assim, a cada dia se acumulam demandas judiciais contra o Estado visando a concretização dos direitos constitucionalmente garantidos, demandas que inserem o Judiciário na rota das disposições orçamentárias, eis que a tutela desses direitos implicará um dispêndio de recursos pelo Poder Público. Diante disso, para além de analisar as implicações orçamentárias 


\section{A jurisprudência do Supremo Tribunal Federal sobre o controle judicial do orçamento público e a proteção dos direitos humanos}

decorrentes da judicialização dos direitos sociais positivos, o objetivo do presente estudo é analisar a postura do Poder Judiciário (STF) com relação ao próprio orçamento, que no Brasil assume a forma de lei e, como tal, está sujeita ao controle formal de constitucionalidade. Existem, no entanto, demandas pelo controle judicial do próprio controle material do orçamento, daí a importância em saber qual a posição do STF sobre o tema, que segue evoluindo através do tempo.

Desse modo, através de uma pesquisa qualitativa de caráter descritivo e exploratório, realizamos análise da doutrina e principalmente da jurisprudência do Supremo Tribunal Federal, por meio da técnica de revisão documental e jurisprudencial. Assim, será possível cumprir o objetivo central do estudo, que é saber como a Corte posiciona-se em relação ao tema, compreendendo a tese fixada e de que modo a decisão contribui para a solução dos conflitos existentes em nossa realidade socioeconômica e cultural, tendo em vista, principalmente, que a Constituição incumbiu todos os Poderes da promoção e proteção dos direitos humanos.

\section{A Jurisprudência do Supremo Tribunal Federal no Controle do Orçamento Público.}

\subsection{Breves noções sobre o orçamento público necessários à contextualização do tema.}

Especialmente em relação ao orçamento público, objeto do nosso estudo, a Constituição trata da matéria a partir do art. 165 da Seção II, mas não só. As principais Leis que complementam a Constituição Federal em relação ao orçamento são as Leis n. 4.320/64 recepcionada e válida - tendo, não obstante, muitos projetos de reforma em andamento ${ }^{3}$ e a Lei Complementar n. 101/2000, chamada de Lei da Responsabilidade Fiscal. Essas leis são conjugadas todo ano pela Lei de Diretrizes Orçamentárias (LDO) e pelo Plano Plurianual (PPA) 2016-2019.

De forma extremamente resumida, podemos dizer que os orçamentos públicos são leis responsáveis por estabelecer as receitas e despesas e definir o que se deve fazer com o dinheiro público, e essa finalidade, segundo o Min. Carlos Ayres Britto no julgamento da ADI n.4.048

\footnotetext{
${ }^{3}$ Dentre elas merece destaque o Projeto de Lei n.229 de 2009 denominada Lei da Qualidade Fiscal.

${ }^{4}$ Cf. especialmente sobre o tema a obra de Luiz Gustavo Bambini de Assis, "Processo Legislativo e orçamento público: a função de controle do parlamento", livro fruto da sua tese de doutorado defendida em 2010, na Universidade Federal de São Paulo - USP, orientada pelo Min. Ricardo Lewandowski.
} 
(p.92 do acórdão), é a mais importante depois da Constituição Federal: “a lei orçamentária é a lei materialmente mais importante do ordenamento jurídico logo abaixo da Constituição. E deixar essa lei do lado de fora do controle de constitucionalidade, em processos objetivos, parece um contrassenso realmente".

Portanto, o orçamento é o produto de um processo deliberativo democrático complexo em que os Poderes Executivo e Legislativo analisam as prioridades públicas e as receitas e decidem o quanto investir em cada área, nos limites dos valores disponíveis e das leis vigentes.

Não obstante, a Constituição, a seu turno, não determinou os procedimentos para que as Políticas Públicas concretizassem os Direitos Fundamentais, o que acabou por compelir a provocação do Judiciário a apreciação de muitos desses direitos. A doutrina comumente denomina o fenômeno de "judicialização das finanças públicas" 5", uma vez que o Judiciário tem sido desafiado, frequentemente, a se manifestar sobre a concretização do mínimo existencial para a garantia de uma vida digna previsto na Constituição Federal.

\subsection{Primeira Fase no STF: a jurisprudência contrária ao controle do orçamento.}

Um dos julgados mais significativos do início da provocação sobre a interferência do STF no orçamento público foi representado pelo julgamento da ADI n. 1640, DJ 03.04.1998 tendo como relator o Min. Sydney Sanches.

Tratava-se de uma Ação Direta de Inconstitucionalidade movida pelos Partido dos Trabalhadores (PT), Partido Comunista do Brasil (PC do B), Partido Democrático Trabalhista (PDT), Partido Socialista Brasileiro (PSB) e Partido Verde (PV), com base nos artigos 102, I, "a" e "p", 103, V, III, da Constituição Federal, sob o fundamento de que a Lei do Orçamento de 1997 violava a disposição Constitucional prevista no $\S 3^{\circ}$ do art. 74 do Ato das Disposições Constitucional Transitórias - ADCT. Isto porque, 27,4\% do produto arrecadado com a contribuição provisória sobre a movimentação financeira (CPMF) estava sendo destinado ao pagamento de dívidas da União e não integralmente à saúde como a Constituição havia determinado. A Presidência da República apresentou defesa alegando que se tratava de uma

5 - Luis Roberto Barroso (2009, p.3) em seu artigo "Judicialização, Ativismo Judicial e Legitimidade Democrática" explica que a judicialização é a ocorrência de constantes provocações para que o judiciário decida sobre questões de "larga repercussão política ou social" que antes eram de exclusiva competência dos Poderes Legislativo e Executivo. 


\section{A jurisprudência do Supremo Tribunal Federal sobre o controle judicial do orçamento público e a proteção dos direitos humanos}

decisão política e parte desses valores estava sendo destinada ao pagamento de empréstimos realizados para o próprio Ministério da Saúde.

O Tribunal, por votação unânime, entendeu pela impossibilidade jurídica do pedido, pois o ato impugnado não teria caráter normativo. O STF entendeu incabível qualquer tipo de controle judicial sobre o orçamento, interpretando que esse não continha normas propriamente ditas, seu texto era redigido em forma de norma, mas seu conteúdo era político administrativo ${ }^{6}$. Confirmava-se, deste modo, a orientação já pacificada na Corte, segundo a qual os atos normativos de efeitos concretos não poderiam ser objeto de ADI - agora aplicada especificamente à lei orçamentária

Quanto ao aspecto político-administrativo da lei, seguiu-se uma orientação antiga no STF, formada no início da Primeira República, quando o STF assentara, verbis:

Considerando, portanto, que, antes do juízo político do Congresso, não pode o Poder Judicial apreciar o uso que fez o Presidente da República daquela atribuição constitucional, e que, também, não é da índole do Supremo Tribunal Federal envolverse nas funções políticas do Poder Executivo ou Legislativo; (Decisão no HC 300, STF, Pleno, Relator Juiz Joaquim da Costa Barradas, Publicada em 27 de abril de 1892).

Surge, deste modo, a doutrina das questões políticas, e o consequente reconhecimento da existência de "assuntos impenetráveis ao controle jurisdicional, mesmo que neles aflorassem questões jurídicas, como é o caso de violação da Constituição, o que se afigura manifestamente contrário aos princípios do Estado de Direito" (Ramos, 2010, p. 145.).

Com efeito, as questões políticas - sua definição, limite e aplicabilidade -, principalmente em relação aos orçamentos públicos, sempre foram e possivelmente continuarão sendo um grande desafio para os Tribunais. Claudio Ari Mello (2004, p.259) alerta que "o problema das questões políticas é delicado e decisivo para o estudo dos limites da justiciabilidade da Constituição", sendo esses um dos pontos considerados na sequência do desenvolvimento da jurisprudência sobre a matéria orçamentária.

\subsection{Segunda Fase no STF: a jurisprudência favorável ao controle formal do orçamento.}

6 - Nesse sentido, a Corte também mencionou as decisões proferidas nas: ADI n.203 (Revista Trimestral de Jurisprudência RTJ-131/1001), ADI n.647 (RTJ-140/36), ADI n.710 (RTJ-156/767), ADI n.767 (RTJ-146/483), ADI n.842 (RTJ-147/545), ADI n.1035 (RTJ-164/48), ADI n.1286 (RTJ-164/897) e ADI n.1496 (RTJ-181/49).

Revista Brasileira de Filosofia do Direito | e-ISSN: 2526-012X | Brasília | v. 3 | n. 1 | p. 18 - 38 | Jan/Jun. 2017. 
Em 19 de dezembro de 2003 esse posicionamento que não admitia nenhum tipo de controle pelo Judiciário nos orçamentos públicos começou a mudar, quando do julgamento da ADI n.2.925 de relatoria da Min. Ellen Gracie e Relator do Acórdão Min. Marco Aurélio.

A ação foi movida pela Confederação Nacional do Transporte, alegando inconstitucionalidade da Lei do Orçamento de 2003 em face do art. 177, § $4^{\circ}$, da Constituição Federal. Argumentava-se que a Lei Orçamentária, na parte em que autorizava abertura de créditos suplementares, não poderia ser aplicada à contribuição de intervenção no domínio econômico incidente sobre as operações realizadas com combustíveis (CIDE), pois a finalidade e destinação dos valores auferidos pela contribuição já estariam taxativamente vinculados na CF, não admitindo, portanto, qualquer dilação.

O Supremo, por maioria, julgou procedente em parte a ação, para fixar a interpretação da CIDE conforme a Constituição, no sentido de que a abertura de crédito suplementar deveria ser destinada às três finalidades enumeradas no art. 177, § 4 , inciso II, alíneas "a", "b" e "c" da CF, e não de forma tão ampla como previsto na Lei do orçamento de 2003.

Nesse momento, a Corte começa a reconhecer a possibilidade de fiscalização das normas orçamentárias mediante o controle formal de constitucionalidade, admitindo que o orçamento público não é única e exclusivamente um ato político, mas um agir estritamente vinculado com as finalidades postas na Constituição Federal.

Em seguida, deu-se o julgamento da ADPF n.63 (julgada em 11.02.2005, Rel. Min. Sepúlveda Pertence), fazendo remissão à ADI n.2.925 para assentar, em obiter dictum, que a falta de abstração e generalidade das normas orçamentárias não mais seria decisivo para a manifestação da Corte. Embora o Ministro Gilmar Mendes, já nesse julgado, tenha registrado a necessidade de que fosse revista a jurisprudência restritiva da Corte sobre o tema, até aquele momento as leis de efeitos concretos não eram passíveis de exame mediante controle abstrato de constitucionalidade, o qual pressupunha a verificação dos atributos de generalidade e abstração dos atos normativos.

Em 2008, a questão sobre a possibilidade do controle das leis orçamentárias pelo STF foi retomada por ocasião do julgamento das ADIs n. 4.048 e n.4.049, Rel. Ministro Gilmar Mendes. A controvérsia era sobre a violação do $\S 3^{\circ}$ do art. $167 \mathrm{CF}$ em relação a Medida Provisória 


\section{A jurisprudência do Supremo Tribunal Federal sobre o controle judicial do orçamento público e a proteção dos direitos humanos}

n.405/2007, convertida na Lei n. 11.658/2008, que determinou a abertura de créditos extraordinários, em favor da Justiça Eleitoral e de diversos órgãos do Poder Executivo no valor acima de cinco bilhões. No caso, a MP não atendia aos requisitos de imprevisibilidade e urgência exigidos pelo art. $165, \S 8^{\circ}$ da Constituição Federal. A discussão dizia respeito ao enquadramento do referido crédito na categoria dos extraordinários, de modo que não estava em questão o conteúdo do crédito extraordinário e si. Teve deferido o pedido cautelar para a suspensão dos efeitos da Lei n. 11.658/2008, momento em que a matéria foi debatida em Plenário. Posteriormente, quando do julgamento do mérito, foi julgada prejudicada pela perda do objeto, uma vez que discutia orçamento passado.

No acórdão, o Relator, Min. Gilmar Mendes, afirmou que “o Supremo Tribunal Federal deve exercer sua função precípua de fiscalização da constitucionalidade das leis e dos atos normativos quando houver um tema ou uma controvérsia constitucional suscitada em abstrato". A importância do voto do Relator está em ter inaugurado um novo panorama jurídico sobre a possibilidade de intervenção do STF como guardião da Constituição Federal em relação as normas do orçamento público. Com efeito, asseverou o Ministro:

(...) a jurisprudência do Supremo Tribunal Federal não andou bem ao considerar as leis de efeitos concretos como inidôneas para o controle abstrato de normas. (...) Ressalte-se que não se vislumbram razões de índole lógica ou jurídica contra a aferição da legitimidade das leis formais no controle abstrato de normas, até porque abstrato - isto é, não vinculado ao caso concreto - há de ser o processo e não o ato legislativo submetido ao controle de constitucionalidade. (...) O Tribunal se vê diante, assim, de um tema ou de uma controvérsia constitucional suscitada em abstrato, independe do caráter geral ou específico, concreto ou abstrato de seu objeto.

O debate materializado no acórdão de 192 páginas é uma importante lição sobre o controle abstrato de constitucionalidade, bem como das visões minoritárias contrárias. Caso semelhante foi analisado na ADI n.4.049 de 2009, em que a tese pró-controle restou reforçada. O Relator desta ação, Min. Carlos Britto, em sintonia com o seu voto proferido na ADI n.4.048, voltou a exaltar a relevância da lei orçamentária para a sociedade ao registrar que "deixá-la de fora do controle de constitucionalidade em processos objetivos parece um dar às costas ao reconhecimento de uma relevância que é tão intrínseca quanto superlativa”.

\subsection{O "estado atual da arte" no STF sobre a interferência judicial no orçamento público}


Mais recentemente - em julho/2016 - foi julgada a ADI n. $5.468^{7}$ na qual o Min. Luiz Fux ratificou o entendimento da Corte pela possibilidade do controle abstrato, e (novidade) pelo "controle material das espécies legislativas orçamentárias, o que corresponderia a uma tendência da recente jurisprudência”. (Grifamos).

No julgamento, a Corte fixou a tese pela possibilidade de realizar, em situações graves $e$ excepcionais, a intervenção do judiciário nas funções do Poder Legislativo de definir receitas e despesas da administração pública. A excepcionalidade deve-se à necessidade de se preservar o princípio da separação dos poderes. Segundo o julgado,

O Tribunal, por unanimidade, aprovou tese fixada nos seguintes termos: "Salvo em situações graves e excepcionais, não cabe ao Poder Judiciário, sob pena de violação ao princípio da separação de poderes, interferir na função do Poder Legislativo de definir receitas e despesas da administração pública, emendando projetos de leis orçamentárias, quando atendidas as condições previstas no art. 166, $\S 3^{\circ}$ e $\S 4^{\circ}$, da Constituição Federal". Ausentes, nesta assentada, os Ministros Gilmar Mendes e Dias Toffoli. Presidência do Ministro Ricardo Lewandowski. Plenário, 30.06.2016. (Grifamos)

A ADI n.5.468 fora movida pela Associação Nacional dos Magistrados da Justiça do Trabalho (Anamatra), questionando o corte de 90\% nas despesas de seus investimentos e de 24,9\% nas de custeio do orçamento de 2016, previsto na Lei Orçamentária de 2016, enquanto que para o restante do Judiciário o corte linear foi de 15\% para custeio e $40 \%$ para investimento. A Associação alega que esse corte de verbas foi realizado sem um mínimo debate técnico, econômico e financeiro e afeta a independência e a autonomia do Poder Judiciário, garantidos no artigo 99 da Constituição Federal. Alega que essa redução orçamentária teria um caráter retaliatório do Parlamento em relação à atuação do Judiciário Trabalhista, principalmente, se comparado ao orçamento aprovado para os demais ramos do Judiciário. Segundo a associação, a medida é uma "chantagem institucional" que visa "enquadrar" a Justiça do Trabalho e "adverti-la acerca dos supostos 'excessos' de seus julgados em detrimento do patronato brasileiro". Desse modo, a Associação requereu ao STF a declaração de nulidade, por inconstitucionalidade, da previsão orçamentária constante na Lei Orçamentária Anual de 2016 referente ao seu orçamento e, cautelarmente, requereu uma determinação à União para que promova em 2016 a execução de $100 \%$ de sua proposta orçamentária encaminhada originariamente pela Justiça do Trabalho ou,

${ }^{7}$ Acórdão ainda não disponibilizado, $C f$. Informativo do STF n.832 de 27 junho a $1^{\circ}$ de julho de 2016, disponível em: http://www.stf.jus.br/arquivo/informativo/documento/informativo832.htm. Acesso em 15.05.2017.

Revista Brasileira de Filosofia do Direito | e-ISSN: 2526-012X | Brasília | v. 3 | n. 1 | p. 18 - 38 | Jan/Jun. 2017. 


\section{A jurisprudência do Supremo Tribunal Federal sobre o controle judicial do orçamento público e a proteção dos direitos humanos}

alternativamente, que aplicasse à Justiça do Trabalho o mesmo percentual realizado aos demais órgãos do Poder Judiciário.

Por outro lado, o Deputado Ricardo Barros ${ }^{8}$ (PP-PR) relator geral do orçamento da União de 2016, justificou sua medida afirmando que a Justiça do Trabalho tem um custo de 17,8 bilhões para o País, o que equivaleria, por exemplo, ao orçamento reduzido de todo o Programa "Bolsa Família". Afirma que a Justiça do Trabalho já conta com 50 mil funcionários e há pedido para a criação de mais 10 mil vagas de trabalho, com o que poderá se tornar a maior empresa empregadora do País. Informa que em 2014 estavam em trâmite 3.544.000 processos, tendo sido julgados 3.396.000 demandas, a demonstrar um indício da ausência de análise qualitativa das demandas. Também alega que é necessário que a Justiça do Trabalho crie um controle sobre seus processos porque, nas palavras do Deputado, "as pessoas que entram na Justiça ou ganham ou não perdem, todos querem ir a um jogo assim”. Finalmente, sugere que a Justiça do Trabalho adote um limite de valor para as demandas, pois seria direito da empresa uma previsão de orçamento sendo que algumas são levadas à falência por conta de reclamatórias, bem como sugeriu que os pedidos realizados pelos reclamantes também tivessem algum ônus, aduzindo que o pressuposto de que o empregado é sempre o hipossuficiente da relação não mais perduraria.

A Corte, através de seu Rel. Min. Luiz Fux, decidiu que o Poder Legislativo exerceu a deliberação orçamentária de forma legal. Afirmou que a jurisdição constitucional não teria capacidade institucional, no controle abstrato, de coordenar o planejamento plurianual e a lei de diretrizes orçamentárias; as condicionantes de emenda orçamentária já teriam sido postas no art. 166 da CF e parágrafos, não prevendo atuação do Judiciário. Referiu que o STF admitia o controle material das espécies legislativas orçamentárias, o que corresponderia a uma tendência da recente jurisprudência da Corte, já tendo admitido o controle abstrato (ADI n.4048 de 2008). Também fez constar que:

Embora a fundamentação apresentada no relatório final da Comissão Mista de Planos e Orçamentos Públicos e Fiscalização do Congresso Nacional ostente motivação ideológica enviesada, esse ato, "per si", não vincularia os parlamentares das Casas Legislativas do parlamento federal. Segundo o Colegiado, ainda quando se avalia cada

\footnotetext{
${ }^{8}$ Cf. Vídeo do Deputado Ricardo Barros, Relator Geral do Orçamento da União de 2016, quando do exercício da sua atividade no Parlamento na parte relacionada a Justiça do Trabalho. Disponível em: https://www.youtube.com/watch?v=1gPvrO_tb1o. Acesso em 03.05.2017.
}

Revista Brasileira de Filosofia do Direito | e-ISSN: 2526-012X | Brasília | v. 3 | n. 1 | p. 18 - 38 | Jan/Jun. 2017. 
um dos subprincípios da proporcionalidade - necessidade, adequação e proporcionalidade em sentido estrito -, a redução do orçamento público destinado a órgãos e programas orçamentários em decorrência de contexto de crise econômica e fiscal não configuraria abuso do poder legislativo.

O Tribunal igualmente não acolheu o pedido da Associação de que o Legislativo teria agido de forma discriminatória, porquanto o procedimento tinha sido realizado dentro da legalidade, com observação de todos os procedimentos. Salientou que a Justiça do Trabalho ainda poderia fazer ajustes solicitando créditos suplementares ${ }^{9}$ (art. $99 \ldots \S 5^{\circ}$ ). Por fim, concluiu que:

O Tribunal deveria estar atento às singularidades institucionais do aparato estatal brasileiro, que se estruturaria a partir de premissas mínimas de programação orçamentária, para permitir que os serviços públicos e as funções estatais típicas possam ser desempenhadas com regularidade, continuidade e adequação, sempre em consonância com as demandas sociais e institucionais submetidas à Corte.

Interessante observar que 3 (três) Ministros, apesar de concordarem com a tese fixada, foram voto vencido quando do julgamento do mérito da ADI, os Ministros Dr. Celso de Mello, Dra. Rosa Weber e o Dr. Presidente Ricardo Lewandowski, em demonstração clara de que a questão não é pacífica na Corte Superior.

Insta frisar que a possibilidade do controle material de constitucionalidade das normas do orçamento público deve ser devidamente contextualizada na tese firmada na ADI n. 5.468, pois não localizamos julgados no STF que tenham efetivamente realizado o controle da matéria do orçamento, frente à Constituição Federal, nos termos propostos nesse estudo.

Não obstante, alguns ministros votaram pela procedência da ADI n.5.468, acenando para além do controle formal, considerando também o conteúdo do orçamento frente ao núcleo hierárquico ${ }^{10}$ de valores fundamentais da Constituição Federal.

\footnotetext{
${ }^{9}$ Importante ressaltar que os créditos suplementares também dependem de autorização do Poder Legislativo, inciso V do art. 167 da CF. Eduardo B. F. de Mendonça (2010, pp.66/67) em sua obra a "A Constitucionalização das Finanças Públicas", esclarece que esses créditos suplementares têm finalidade de reforçar o orçamento e normalmente o pedido já consta no orçamento anual conforme autorizado pelo art. 165, § $8^{\circ}$ da CF com "condições e limitações".

${ }^{10}$ Ávila (2016, n.105), em ensaio intitulado "Reflexões sobre o Controle Judicial de Gastos Públicos no Brasil", demonstra uma graduação de valores presente na própria Constituição Federal: "muitas deduções lógicas podem decorrer desta leitura sistemático-axiológica do texto constitucional: no topo da escala hierárquica estarão as normas que garantem o direito social à saúde, que é um pressuposto para a realização de diversas normas de direitos fundamentais de dimensão individual, tais como à existência digna, à integridade física e psíquica e das liberdades em geral. Ao seu lado estarão as normas que asseguram o direito social à educação, indispensáveis para as liberdades de pensamento, de expressão, de informação, de escolha do ofício ou profissão, bem como para o exercício dos direitos políticos de votar e ser votado etc. A segurança, a seu turno, é o que garante o exercício da liberdade,
}

Revista Brasileira de Filosofia do Direito | e-ISSN: 2526-012X | Brasília | v. 3 | n. 1 | p. 18 - 38 | Jan/Jun. 2017. 
O Ministro Ricardo Lewandowski concordou com a alegação da Anamatra, ratificando o entendimento da Associação de que a Justiça do Trabalho estaria sendo discriminada, através do orçamento, numa conjuntura de flexibilização de direitos sociais:

O Ministro Presidente entendia haver vício na motivação que teria levado os parlamentares a promoverem corte desarrazoado e desproporcional em relação aos demais Poderes. Realçava que a Justiça do Trabalho estaria sendo discriminada num contexto em que se prega a flexibilização dos direitos sociais e a remessa das disputas trabalhistas para uma solução privada.

O Min. Celso de Mello e a Min. Rosa Weber também votaram pela procedência da ação, ingressando na análise político jurídica da matéria posta no orçamento de 2016. Entenderam que não se questiona as competências exclusivas do Poder Executivo e Legislativo no que tange ao Orçamento Público, contudo aduzem que esse poder não pode ser absoluto. É necessário, em respeito a própria Constituição Federal, que haja uma fiscalização da destinação orçamentária. Por isso, na decisão noticiada

O Ministro Celso de Mello reconhecia que a manipulação do processo de formação, elaboração e execução da Lei Orçamentária Anual poderia atuar como instrumento de dominação de outros Poderes da República por aquele encarregado da gestão da peça orçamentária. Isso poderia culminar em um estado de submissão financeira e de subordinação orçamentária incompatível com a autonomia que a própria Constituição outorgou. Apontava que não se questiona a exclusividade do poder de iniciativa do chefe do Poder Executivo em matéria orçamentária ou a atribuição do Poder Legislativo de elaborar a legislação orçamentária, mas sim, se o Congresso Nacional, no desempenho formal dessa atribuição que a Constituição lhe confere pode ou não formular provimentos legislativos eventualmente deformados quanto ao seu conteúdo pela eiva do caráter arbitrário de suas disposições. Destacava que a competência legislativa não teria caráter absoluto, não poderia ser exercida de modo excessivo, arbitrário ou irresponsável, sob pena de se subverter os fins a que se dirige a função legislativa. (Grifamos).

Continua seu voto referindo que, caso o Poder Legislativo tome decisões com abuso de poder, de forma irresponsável ou arbitrária na aplicação das verbas públicas é de fundamental importância que o STF, como guardião da CF e, por consequência, protetor dos valores fundamentais, tenha meios para coibir esses abusos. Argumenta, nesse sentido, que

um dos efeitos perversos do abuso do poder de legislar, em especial no plano da legislação orçamentária, consistiria em sua projeção negativa e lesiva sobre a integridade dos mecanismos institucionais de proteção jurisdicional, com grave repercussão sobre o exercício de direitos essenciais e de liberdades fundamentais,

também no topo da escala de prioridades. E de todos os direitos fundamentais, aqueles de que sejam titulares crianças e adolescentes são os mais prioritários para os investimentos governamentais, em decorrência do art. 227 da Constituição: o fragmento "absoluta prioridade" é preclusivo de maiores ilações".

Revista Brasileira de Filosofia do Direito | e-ISSN: 2526-012X | Brasília | v. 3 | n. 1 | p. 18 - 38 |

Jan/Jun. 2017. 
especialmente no campo delicado dos direitos sociais da classe trabalhadora. Asseverava que de nada valeriam os direitos e as liberdades se os fundamentos em que se apoiam deixaram de contar com o suporte do Poder Judiciário, que poderia ficar paralisado pela ausência de recursos orçamentários necessários ao regular funcionamento de seus órgãos. Lembrava que, uma vez alcançado determinado nível de concretização em tema de direitos fundamentais de caráter social, o princípio da proibição do retrocesso impediria que fossem desconstituídas as conquistas alçadas pelos cidadãos ou, no contexto em exame, pelos empregados e trabalhadores, que estariam impossibilitados de transformar em realidade concreta os direitos abstratamente previstos no ordenamento positivo. Assegurava que o retrocesso social poderia comprometer o núcleo essencial de valores fundamentais, como os direitos sociais da classe trabalhadora, colocados em situação de evidente lesividade (Grifamos).

Em relação à jurisprudência do STF sobre o orçamento público, importa também destacar outro processo - Recurso Extraordinário n. 858.075 - acolhido com Repercussão Geral, relativo à aplicação de recursos orçamentários mínimos nas ações e serviços públicos de saúde, mesmo antes dos percentuais mínimos estabelecidos pelo $\S 2^{\circ}$ e seus incisos do art. 198 da CF, pendente de julgamento do mérito, concluso com o Min. Marco Aurélio.

Realmente, não nos parece possível que o Poder Judiciário possa gerir o orçamento público, não obstante, é necessário que efetive o seu compromisso de protetor dos ditames Constitucionais, considerando o bem comum entrelaçado ao princípio da proporcionalidade. Nesse particular, David Beatty (2014, p. 251) esclarece que

muito mais importante que as palavras e a excelência do texto é a justiça distributiva envolvida no pedido requerente. Tenha a demanda o objetivo de obter assistência médica, educação ou simples dinheiro, o fator decisivo é a pertinência da reivindicação em relação ao princípio da proporcionalidade e a ideia de distribuição equitativa (...).

Tal linha argumentativa remete aos fundamentos que possam ser invocados para justificar alguma atuação judicial fiscalizatória do conteúdo do orçamento. No ponto, a proteção dos direitos humanos e a eficácia dos direitos fundamentais exercem relevante papel.

\section{Dos fundamentos subjacentes ao controle do orçamento: entre a proteção dos direitos humanos e a separação dos poderes}

A efetivação de qualquer direito traz alguma repercussão financeira e realizá-los depende do direcionamento das finanças públicas, o que por sua vez, depende de decisões políticas dos Poderes Legislativo e Executivo. Nada obstante certa liberdade de conformação deferida às decisões políticas, os poderes políticos não podem agir de forma totalmente discricionária no 


\title{
A jurisprudência do Supremo Tribunal Federal sobre o controle judicial do orçamento público e a proteção dos direitos humanos
}

momento do planejamento orçamentário, muito pelo contrário, devem focar em uma gestão eficiente direcionada à efetivação dos Direitos Fundamentais ${ }^{11}$, cuja hierarquia de valores já foi previamente posta na Constituição Federal.

A proteção constitucional aos direitos fundamentais significa que certas decisões já foram previamente cristalizadas no texto de maior estatura jurídica e que conforma e limita todos o exercício de poder estatal. Por tal razão, uma constituição que institua um sistema de direitos fundamentais "não está autorizada a entregar a concretização legal desses direitos à livre administração dos processos democráticos” (Mello, 2004, p. 147).

Ingo Wolfgang Sarlet (2001, p.71), ao referir a nova ordem constitucional de 1988, afirma que "a mudança mais expressiva tenha sido as normas de proteção aos Direitos Fundamentais, inclusive incluindo-os como Cláusulas Pétreas art. $60 § 4^{\circ}$, impedindo a supressão e erosão dos preceitos relativos aos direitos fundamentais pela ação do poder Constituinte derivado". Ao discorrer sobre a eficácia dos direitos fundamentais, Sarlet ressalta que vão muito além de meros norteadores de condutas aos poderes públicos quando da realização dos orçamentos, são verdadeiras imposições Constitucionais:

\begin{abstract}
No que diz com a eficácia dos direitos fundamentais propriamente ditas, há que ressaltar o cunho eminentemente principiológico da norma contida no art. $5^{\circ}, \S 1^{\circ}$, da nossa Constituição, impondo aos órgãos estatais e aos particulares (ainda que não exatamente da mesma forma), que outorguem a máxima eficácia e efetividade aos direitos fundamentais, em favor dos quais (seja qual for a categoria a qual pertençam e consideradas as distinções traçadas) milita uma presunção de imediata aplicabilidade e plenitude eficacial (Sarlet, 2001, p. 377/8).
\end{abstract}

Porém, se de um lado a Constituição Federal estipula um rol de direitos fundamentais como metas a serem perseguidas pelos poderes de modo a concretizar a dignidade da pessoa humana, por outro não determinou os procedimentos para que esses objetivos fossem cumpridos. A liberdade no manejo dos meios de concretização dos direitos pode levar a situações fáticas incongruentes com a previsão normativa, tais como: a educação brasileira tem um dos índices

${ }^{11}$ Cf. artigo de Fábio Konder Comparato (1998), "Ensaio sobre o juízo de Constitucionalidade de Políticas Públicas". Nesse escrito o autor faz uma incursão no conceito de Estado e autoridade da Lei para Locke, Montesquieu e Rousseau, passando pelas Constituições Liberais culminando na nossa atual Constituição Federal. Explica que nesse inaugurado "Estado Social" o objetivo fim é proteger a dignidade da pessoa humana através de Políticas Públicas vinculantes a todos os órgãos do Estado. Sugere uma reforma Constitucional para que se determine, dentre outras, a forma processual e a competência judiciária, todavia, em que pese seu parecer, reconhece que o Judiciário tem o dever de proteger a Constituição, porém termina o artigo questionando se esse terá as competências técnicas e éticas necessárias para cumprir essa função.

Revista Brasileira de Filosofia do Direito | e-ISSN: 2526-012X | Brasília | v. 3 | n. 1 | p. 18 - 38 |

Jan/Jun. 2017. 
mais baixos do mundo (ver dados do Programa Internacional de Avaliação dos Estudantes PISA/2016 realizada pela OCDE); pessoas morrem nas filas de hospitais por falta de atendimento; o sistema penitenciário está completamente falido ${ }^{12}$; e, apesar dessas situações, nos deparamos com, por exemplo, a doação de vinte milhões à República do Paraguai (Lei n.11.444 de 5.01.2007).

Nesse contexto de provável mau uso do dinheiro público somado à ausência de confiança nos Poderes Legislativo e Executivo, no qual teve bastante relevância a publicização dos recentes episódios de corrupção presentes na destinação dos recursos públicos, o STF está sendo cada vez mais instigado a exercer a função de protetor dos direitos fundamentais positivados na Constituição Federal, inclusive daqueles que exigem o dispêndio de verba pública para sua proteção. Esta função de controle gera muito debate em torno da falta de legitimação democrática dos juízes, sendo este um dos debates centrais na teoria constitucional. Nas palavras de Ely,

esta é a função central, e ao mesmo tempo o problema central da revisão judicial: um colegiado que não é eleito e nem politicamente responsável em qualquer modo significante diz aos representantes eleitos pelo povo que eles não podem governar como eles gostariam (Ely, 1998, p. 4 - tradução nossa).

Ao contrário, para Barroso (2009, p.12), essa função de controle dos atos do poder público pelos tribunais constitucionais somente corrobora com a proteção da democracia. Para ele, "a jurisdição constitucional bem exercida é antes uma garantia para a democracia (...)".

Claudio Ari Mello (2004, pp. 188; 185/186) explica que as críticas contra a intervenção do Judiciário nas políticas públicas, sob o argumento de fragilizar ou até mesmo eliminar com a democracia, partem de um conceito "unidimensional do fenômeno democrático", contudo, orienta que "uma democracia constitucional é um regime político bem mais complexo, que distribui canais de deliberação e decisão da vida comunitária de modo bem mais abrangente”, e complementa:

A garantia dos direitos fundamentais, tanto os liberais e políticos quanto os sociais, depende de um Poder Judiciário ativo e capaz de exercer uma vigilância jurídica sobre o processo político de concretização da constituição. Não é possível nem uma confiança cega na democracia deliberativa, nem uma desconfiança total em relação a política. Uma constituição democrática impõe limites e direção ao processo político, e o controle do

${ }^{12} C f$. Acórdão resultante do julgamento da liminar na Ação de Descumprimento de Preceito Fundamental - ADPF n.347 de relatoria do Min. Marco Aurélio, publicação ocorrida em: 11.09.2015. DJE n. 181, 210 p. 
respeito desses vetores é tarefa indelegável da jurisdição. (...). Os bens e valores que preenchem o conteúdo dos princípios e direitos fundamentais orientam, predeterminam e limitam o espaço de decisão da democracia deliberativa. No entanto, sem a garantia do recurso à jurisdição constitucional, a pré-determinação e a limitação constitucionais do processo democrático seriam inoperantes.

Em relação ao controle do conteúdo das disposições orçamentárias, Ávila e Wierzchowski (2013, p.210/211) ratificam essa conclusão e sublinham que

como os parâmetros para a correção do orçamento advém da própria Constituição e o seu guardião é o STF, o silogismo é evidente: a ele compete o controle daquela exigência de simetria formal e material em face da matriz constitucional. Diante disso, a conclusão que pode ser inferida é que a constitucionalização do orçamento, em seus aspectos formais e materiais, faz com que a lei orçamentária se torne objeto de controle judicial.

Discorrendo especificamente sobre o tema do controle das escolhas orçamentárias, Alceu Maurício Jr. (2007, p.3) refere que o princípio da separação dos poderes não é "uma barreira absoluta à revisão judicial de decisões sobre a alocação de recursos no Estado, mas exige o respeito - e até uma precedência - das decisões tomadas pelos órgãos políticos. É necessário, então, buscar critérios que tracem as fronteiras da atuação do Judiciário na revisão das escolhas orçamentárias".

Contudo, da admissão desta função fiscalizatória do STF em relação ao cumprimento das diretrizes constitucionais pelos poderes Públicos, não decorre que o tribunal poderá agir de forma a macular a democracia ou o princípio da separação dos poderes. É necessário encontrarmos um equilíbrio entre a proteção fiscalizadora e a intervenção desregrada. Com efeito,

(...) os juízes da democracia constitucional, ao receberem o encargo de guardiões da constituição, comprometem-se a ser os principais responsáveis pelo equilíbrio de um sistema político-jurídico do qual eles próprios são peças-chave. Isso significa que eles nem podem omitir-se e tolerar uma inaceitável soberania parlamentar indiferente ao programa constitucional, nem podem reclamar o monopólio da interpretação constitucional para impor uma supremacia judicial que iniba ou asfixie a cultura republicana (Mello, 2004, p. 200-1).

Nesse mesmo sentido Felipe de Melo Fonte (2009, p.16) acrescenta:

Sobre a suposta violação ao princípio da separação dos poderes, de há muito se entende que é descabida a afirmação de que as funções estatais supõem estrita especialização funcional. De fato, regra geral os poderes devem seguir sua atividade principal, mas nada impede que os mesmos incursionem nas atividades dos demais. O princípio da separação dos poderes não é e nem precisa ser de uma rigidez inquebrantável para servir a sua principal função: conter o arbítrio. Pelo contrário, sua aplicação cega pode acabar tendo a função inversa. Note-se, ademais, que não se trata de uma revogação do princípio, mas sim de sua derrogação pontual. O Poder Judiciário não estará habilitado

Revista Brasileira de Filosofia do Direito | e-ISSN: 2526-012X | Brasília | v. 3 | n. 1 | p. 18 - 38 | Jan/Jun. 2017. 
ao controle irrestrito de qualquer política pública, mas sim somente em relação àquelas sensíveis aos direitos fundamentais.

Paulo Bonavides (2007, pp.64/65) reconhece todo o valor do princípio da separação dos poderes, principalmente antes da vigência do "Estado Social" implementado com a Constituição Federal de 1988; contudo afirma que "pretender, porém, conservá-lo como dogma em justificações descabidas para a atualidade, é o que nos parece inaceitável (...). A separação de poderes é, como vimos, técnica em declínio, sujeita a gradual superação imposta por requisitos novos de equilíbrio político e acomodação a esquemas constitucionais (...)”.

Desse modo, a Constituição Federal não somente determinou os direitos fundamentais com o objetivo de assegurar uma existência humana digna, mas também estabeleceu uma escala norteadora para que os poderes, em conjunto e de forma coordenada, implementem essas políticas públicas e o orçamento público é peça fundamental para essa concretização. Restará ao STF o desafio de otimizar tanto as normas de direitos fundamentais como aquelas que estabelecem as competências e capacidades institucionais de cada um dos poderes estatais, encontrando soluções que, de um lado, garantam o atendimento mínimo daqueles direitos, e, de outro, evitem a usurpação das responsabilidades dos outros órgãos investidos de poderes pela Constituição Federal.

Um exemplo de equacionamento deste tipo de impasse pode ser colhido em um precedente do STJ do ano de 2003, em que a Relatora, Min. Eliana Calmon, determinou ao município o dever de reservar, no orçamento do ano seguinte, verba suficiente para a implementação do programa de atendimento a alcoólatras e toxicômanos lançado no programa de Governo do Executivo municipal, mas que deixara de ser executado por falta de recursos. A decisão foi assim ementada:

ADMINISTRATIVO E PROCESSO CIVIL -AÇÃO CIVIL PÚBLICA -ATO ADMINISTRATIVO DISCRICIONÁRIO: NOVA VISÃO. 1. Na atualidade, o império da lei e o seu controle, a cargo do Judiciário, autoriza que se examinem, inclusive, as razões de conveniência e oportunidade do administrador. 2. Legitimidade do Ministério Público para exigir do Município a execução de política específica, a qual se tornou obrigatória por meio de resolução do Conselho Municipal dos Direitos da Criança e do Adolescente. 3. Tutela específica para que seja incluída verba no próximo orçamento, a fim de atender a propostas políticas certas e determinadas. 4. Recurso especial provido REsp 493.811/SP 2002/0169619-5, Rel. Min. Eliana Calmon. STJ, $2^{a}$ Turma, 10/11/2003. (grifamos) 


\section{A jurisprudência do Supremo Tribunal Federal sobre o controle judicial do orçamento público e a proteção dos direitos humanos}

O interessante neste julgado é que o Tribunal não fixou, ele próprio, a verba a ser despendida pelo Executivo no programa em questão, limitando-se a orientar as autoridades responsáveis pela elaboração do orçamento quanto ao dever de considerar a prioridade dessa política pública. De resto, este tipo de decisão expressa uma tendência que vem sendo gradualmente implementada na jurisprudência do STF em matéria de direitos sociais e controle de políticas públicas, em que o órgão judicial intervém nessas situações impondo aos órgãos responsáveis que realizem diagnósticos das situações de sua competência e elaborem planos de ação adequados para suprir o quadro de omissão nas políticas públicas. Trata-se da chamada teoria do diálogo institucional, preconizando que o Judiciário assuma o papel de monitoramento dos poderes responsáveis para que cumpram, dentro de suas capacidades e competências constitucionais, os papeis que lhes incumbem no plano de implementação dos direitos fundamentais.

O tema encontrou eco na decisão em medida cautelar na ADPF 347 (Rel. Min. Marco Aurélio), ação que requeria a intervenção do Judiciário na reforma da política carcerária brasileira e envolvia o tema da aplicação dos recursos do FUNPEN (fundo penitenciário instituído na LC 79/1994), que eram objeto de sucessivos contingenciamentos por parte do governo e não eram destinados à revitalização do sistema prisional. A ação aguarda decisão final, mas a medida cautelar, desde logo, já impõe que a Administração Pública se abstenha de novos contingenciamentos e realize um plano de ações conjuntas para a melhoria do sistema carcerário. Quem sabe, não seja esta uma solução possível neste tipo de impasse envolvendo as escolhas orçamentárias que possibilite ao STF um caminho entre a omissão judicial total, algo indesejável do ponto de vista do combate à inefetividade dos direitos fundamentais assegurados na Constituição, e a usurpação das funções dos demais poderes, algo indesejável do ponto de vista da democracia e da separação dos poderes.

\section{Considerações Finais}

Revista Brasileira de Filosofia do Direito | e-ISSN: 2526-012X | Brasília | v. 3 | n. 1 | p. 18 - 38 | Jan/Jun. 2017. 
Esse trabalho está inserido em um contexto maior, que examina o controle da constitucionalidade material do orçamento e seu objetivo, nesta ocasião, foi apenas o de demonstrar a evolução da jurisprudência do Supremo Tribunal Federal quanto ao tema, iniciando pela impossibilidade de controle do orçamento pelo Judiciário, até o atual estado da arte, presente no posicionamento que culminou na fixação da tese decorrente do recente julgamento (julho/2016) da ADI n. 5.468. Nosso estudo teve por foco, muito além do reconhecimento das implicações orçamentárias decorrentes da judicialização dos direitos sociais e liberais, aclarar a orientação do STF, considerando, principalmente, que a elaboração do orçamento público é de competência dos Poderes Legislativo e Executivo e fundamental para concretizar os direitos humanos.

Constatamos que o STF, diante do atual contexto social - cuja publicização de episódios de corrupção relacionados ao mau uso do orçamento público, tem sido frequentemente instigado a se posicionar, de modo efetivo, como guardião da $\mathrm{CF}$, dentro de um quadro maior de descaso institucional em que a escassez de recursos e a precarização dos direitos fundamentais se notabilizam.

Vimos que a Constituição Federal determinou os valores fundamentais a serem resguardados num Estado Democrático de Direito de modo a permitir uma escala prioritária a determinadas áreas, vinculando os Poderes a agirem de forma conjunta e coordenada, com o objetivo final de proteção da dignidade da pessoa humana. Apesar disso, muitas normas possuem alto grau de abstração que delegam aos poderes responsáveis a competência para conformarem os meios que promovam os fins constitucionais e ao Judiciário a competência para interpretar e proteger os bens assegurados naquelas normas.

Assim, num primeiro momento, verificou-se que a Corte sequer admitia que o orçamento público continha normas, afirmava que sua forma era de lei, mas seu conteúdo era totalmente administrativo, tornando, portanto, impraticável qualquer controle de constitucionalidade. Em seguida, passou a admitir a possibilidade de impugnação da lei orçamentária pela fiscalização abstrata de constitucionalidade e, mais recentemente admitiu que além da possibilidade de controle formal, também seria possível o controle material. 
Contudo, no STF não localizamos julgados, decisões majoritárias, que realmente tivessem realizado o controle de constitucionalidade material das leis orçamentárias, o que há sim, são alguns votos esparsos nesse sentido. A despeito disso, a Corte fixou tese jurídica admitindo a possibilidade de realizar, em situações graves e excepcionais, a intervenção do Judiciário nas funções do Poder Legislativo de definir receitas e despesas da administração pública.

Isso admite, em tese, o controle das escolhas orçamentárias nessas circunstâncias "graves e excepcionais", termos que deverão ser futuramente esclarecidos na jurisprudência da Corte. Contudo, a análise das decisões aqui examinadas permite desde logo uma prognose, no sentido de que o STF, se confrontado com situações de tal gravidade (como seria o caso da omissão e descaso em face da população carcerária, que deu origem à ADPF 347), caminhará no sentido da preservação das capacidades institucionais de cada Poder, agindo como um articulador para incentivar e monitorar o desempenho dos papeis dos órgãos responsáveis. No caso do orçamento, isso significa que, ao detectar distorções orçamentárias graves, deve o STF reenviar o plano orçamentário às autoridades responsáveis, determinando que o gasto público reflita, com simetria, o atendimento das áreas prioritárias e dos direitos fundamentais protegidos pela Constituição.

\section{REFERÊNCIAS BIBLIOGRÁFICAS.}

ASSIS, Luiz Gustavo Bambini de. Processo Legislativo e orçamento público: função de controle do Parlamento. São Paulo: Saraiva, 2012.

ÁVILA, Ana Paula. Reflexões sobre o Controle Judicial de Gastos Públicos no Brasil. Porto Alegre/RS, ano 2016, nº 105. Disponível em:

http://www.direitodoestado.com.br/colunistas/Ana-Paula-Oliveira-Avila/reflexoes-sobre-ocontrole-judicial-do-gasto-publico-no-brasil. Acesso em: 22.11.2016.

ÁVILA, Ana Paula; WIERZCHOWSKI, Mariana Ruschel. "Fair Play" judicial na efetivação dos direitos sociais. Direitos Fundamentais \& Justiça, ano 7, n. 23, Abr/Jun. 2013.

BARROS, Ricardo, deputado. Relator Geral do Orçamento da União de 2016. Vídeo da sua atuação no Parlamento na parte relacionada a Justiça do Trabalho. Disponível em: https://www.youtube.com/watch?v=1gPvrO_tb1o . Acesso em 03.05.2017.

BARROSO, Luís Roberto. Fundamentos Teóricos e Filosóficos do Novo Direito

Constitucional Brasileiro (Pós Modernidade, teoria crítica e pós positivismo). Revista Diálogo Jurídico. Salvador/BA, ano 2001, Vol. 1 nº. 6. Disponível em: 
Ana Paula Oliveira Ávila \& Daniella Bitencourt

file://C:/Users/danie/Desktop/ANA\%20PAULA/BARROSO\%20Fundamenos\%20Novo\%20Dir eito\%20Constitucional.pdf. Acesso em: 22.03.2017.

BARROSO, Luís Roberto. Judicialização, Ativismo Judicial e Legitimidade Democrática.

Disponível em:

http://www.oab.org.br/editora/revista/users/revista/1235066670174218181901.pdf. Acesso em: 04.05.2017.

BEATTY, David M. A essência do Estado de direito. São Paulo: Martins Fontes, 2014.

BONAVIDES, Paulo. Do Estado Liberal ao Estado Social. $8^{\circ}$ Edição. São Paulo: Malheiros, 2007.

BRASIL, Portal do Supremo Tribunal Federal. Disponível em:

http://www.stf.jus.br/portal/principal/principal.asp. Consulta efetuada em 23.11.2016.

BRASIL. Constituição (1988). Constituição: República Federativa do Brasil. Disponível em: http://www.planalto.gov.br/ccivil_03/constituicao/constituicao.htm. Acesso em 12.05.2017.

BRASIL. Superior Tribunal de Justiça - STJ, Recurso Especial - Resp. n.493.811. Recorrente: Ministério Público do Estado de São Paulo, Recorrido: Município de Santos. Min. Eliana Calmon Relatora, Segunda Turma. Julgado em: 11.11.2003, Publicação ocorrida em: 15.03.2004.

BRASIL. Supremo Tribunal Federal - STF, Ação Direta de Inconstitucionalidade - ADI n.1.640. Requerentes: Partido dos Trabalhadores - PT e outros, Intimado: Presidente da República e Congresso Nacional. Min. Sydney Sanches Relator. Julgado em: 12.02.1998, Publicação ocorrida em: 03.04.1998 - Ata n. 09.98.

BRASIL. Supremo Tribunal Federal - STF, Ação Direta de Inconstitucionalidade - ADI n.2.925. Requerentes: Confederação Nacional do Transporte - CNT, Intimado: Presidente da República e Congresso Nacional. Min. Ellen Gracie Relator. Min. Marco Aurélio Redator para o Acórdão. Julgado em: 19.12.2003, Publicação ocorrida em: 19.12.2003 - Ata n. 38.03.

BRASIL. Supremo Tribunal Federal - STF, Ação Direta de Inconstitucionalidade - ADI n.4.048. Requerentes: Partido da Social Democracia Brasileira - PSDB, Intimado: Presidente da República. Min. Ellen Gracie Relatora. Liminar objeto do debate julgada pelo Pleno em: 14.05.2008, publicação ocorrida em: 23.05.2008, DJE n. 93. Mérito julgado em 17.02.2011, publicado em 21.02.2011 DJE n. 35.

BRASIL. Supremo Tribunal Federal - STF, Ação Direta de Inconstitucionalidade - ADI n.4.049. Requerentes: Partido da Social Democracia Brasileira - PSDB, Intimado: Presidente da República. Min. Ellen Gracie Relatora. Liminar objeto do debate julgada pelo Pleno em: 05.11.2008, publicação ocorrida em: 12.11.2008, DJE n. 215. Mérito julgado em 10.03.2016, publicado em 15.03.2016 DJE n. 49.

BRASIL. Supremo Tribunal Federal - STF, Ação Direta de Inconstitucionalidade - ADI n.5.468. Requerentes: Associação Nacional dos Magistrados da Justiça do Trabalho - ANAMATRA, Intimado: Congresso Nacional. Min. Luiz Fux Relator. Julgado em: 29.06.2016, Publicação ocorrida em: 02.08.2016. DJE n. 161. Acórdão ainda não disponibilizado, $C f$. Informativo do STF n.832 de 27 junho a $1^{\circ}$ de julho de 2016 , disponível em: 
http://www.stf.jus.br/arquivo/informativo/documento/informativo832.htm. Acesso em 15.05.2017.

BRASIL. Supremo Tribunal Federal - STF, Arguição de Descumprimento de Preceito Fundamental - ADPF n.63. Requerentes: Governador do Estado do Amapá, Intimado: Assembleia Legislativa do Estado do Amapá. Min. Dias Toffoli Relator. Julgado em: 03.02.2005, Publicação ocorrida em: 03.02.2005.

BRASIL. Supremo Tribunal Federal - STF, Arguição de Descumprimento de Preceito Fundamental - ADPF n.347. Requerentes: Partido Socialismo e Liberdade - PSOL e outros, Intimados: União, Distrito Federal e os outros 26 Estados da Federação. Min. Marco Aurélio Relator. Liminar deferida em parte julgada em 09.09.2015, Publicação ocorrida em: 11.09.2015. DJE n. 181.

COMPARATO, Fábio Konder. Ensaio sobre a Constitucionalidade de Políticas Públicas. Revista de Informação Legislativa, Brasília, Vol. n.138, pp. 39/48, abr/jun, 1998.

ELY, John Hart. Democracy and Distrust - A Theory of Judicial Review. Cambridge: Harvard University Press, 1998.

FONTE, Felipe de Melo. A Legitimidade do Judiciário para o Controle de Políticas Públicas. Revista Eletrônica de Direito Administrativo e Econômico - REDAE, Salvador/Bahia, n.18, pp. 1/35, mai/jun/jul, 2009.

FUX, Luiz. Orçamento Público na Jurisprudência do STF: a possibilidade de controle judicial, a autonomia constitucional orçamentária e a problemática do orçamento participativo. Brasília, 2011. Disponível em: http://bdjur.stj.jus.br/jspui/bitstream/2011/101250/orcamento_publico_jurisprudencia_fux.pdf. Acesso em: 06.04.2017.

MAURÍCIO JR., Alceu. A revisão judicial das escolhas orçamentárias e a efetivação dos direitos fundamentais. Revista Diálogo Jurídico Online, n. 15, jan/2007, Salvador.

MELLO, Claudio Ari. Democracia Constitucional e Direitos Fundamentais. Porto Alegre: Livraria do Advogado, 2004.

MENDONÇA, Eduardo Bastos Furtado de. A Constitucionalização das Finanças Públicas no Brasil. Rio de Janeiro: Renovar, 2010.

SARLET, Ingo Wolfgang. A Eficácia dos Direitos Fundamentais. $2^{\mathrm{a}}$ Ed, Porto Alegre: Livraria do Advogado, 2001. 